水文・水资源学 会誌

J. Japan Soc. Hydrol, \& Water Resour.

\begin{tabular}{ll} 
Vol. 10, No. 3 (1997) & pp. 259-269 \\
\hline
\end{tabular}

\title{
リスク解析による渴水レベルに応じた対応方策の評価
}

\section{Evaluation of Drought Remedial Policies Based by Risk Analysis}

\author{
田尻 要* \\ Kaname TAJIRI \\ 神野健二**・河村 明** \\ Kenji JINNO • Akira KAWAMURA
}

\author{
（西松建設侏技術研究所） \\ Technical Research Institute, Nishimatsu Construction Co , , Ltd . \\ (九州大学工学部建設都市工学科) \\ Dept. of City Construction Engineering, Kyusyu University.
}

\begin{abstract}
It is awared that decreasing precipitation of recent years has propelled a declining safety of water in urban areas. As a countermeasure, efforts are focused on expanding the use of existing water resources, and refining sea water for general use. In order to execute these policies, it is necessary to evaluate quantitatively the safety aspects maintained at each local government concerned with water management, in assessing the drought scenario. In this article, for evaluating the water system safety, reliability, resiliency, vulnerability, and also additional DRI (Drought Risk Index) are defined. Further, ACity, as our hypothetical study area, is examined for the effects of remedial policies for drought in the surrounding local governments during those droughts in years 1992 and 1994.
\end{abstract}

Key words: Drought, Risk analysis, Water management safety, Expanded water resources

近年の少雨傾向により, 都市圈の利水安全度は実質的に低下していると考えられている. 利水安全度の低下に対する方策として, 水資源の広域利用化や安定水源として海水淡水化の学入などが着目されている.このような方策を実現するためには, 想定される渴 水レベルに応じて利水安全度の応答を定量的に把握し評価でる体制の確立が必要である.そこで本研究では, 利水安全度の評価に リスク解析を導入し, 信頼度, 回復度, 深刻度および新たに総合的な指標としてDRI (Drought Risk Index)を定義した. 本報では, 想定する渴水レべルの事例として, A 都市圈の中心都市であるA市における平成 4 年度および平成 6 年度の渴水を対象に, A市の水 資源を周辺自治体へ臨通することおよび安定水源の確保という渴水対策が利水安全度に与える影響や効果を検討した. シミュレー ションによって求められるDRIをはじめとしたリスク指標を検討することは, 水道事業の広域化や水瓷源計画など, 施策の検討や効 果の予测を評価する上で有効な手法であることを示した。

キーワード：渴水, リスク解析, 利水安全度, 広域利水

\section{I 、はじめに}

近年, 平成 6 年度のように全国的な大規模渴水に 限らず，各地で小規模な渴水が頻繁に発生しており， 確率渴水年で $1 / 10$ 年という水資源計画における利水 安全度は実質的に低下していると考えられている1． 利水安全度の向上を目指した長期的な方策として, 各自治体や水道企業団等は，水源の開発や施設の整 備の促進などを実施しており効果を上げているが,
ダム建設適地の不足，諸用水間の競合激化，㻴境保 全上の問題などから大規模な水資源開発は困難に なっている ${ }^{2 \sim 4)}$.このような利水安全度の低下と水資 源開発の現状に対して,水資源の広域利用化 ${ }^{2,5 \sim 7)}$, 安定的に確保できる水源，例えば気候変動の影響を 受けにくい海水の淡水化が注目されている。

水資源の広域利用とは，水源や施設の統合および 配水管路の連結を行うことで水供給ネットワークを 構築して自治体間における水の融通を行い, 水源の

\footnotetext{
“西松建設㮫技術研究所 $=242$ 神奈川県大和市下鶴間2570-4

Technical Research Institute, Nishimatsu Construction Co., Ltd. 2570-4, Shimotsuruma, Yamato Kanagawa, 242, Japan

**九州大学工学部建設都市工学科

Dept. of City Construction Engineering, Kyusyu University
} 
有効利用と渴水への対応力の向上によって渴水時に おける安定的な水資源確保と利水安全度の向上を目 指した方策である．水道事業を広域的に一元化する ことは，水資源賦存量の格差の是正，渴水に対する 弾力性の向上, スケールメリットによる維持コスト の軽減など数多くの長所がある反面,これまでの水 道事業の歴史や料金体系の相違など，事業の再編が 容易ではない実態がある，水資源の偏在性のために 広域利用化の実現が望まれる地域においては，時間 をかけて社会環境との調和を充分に図るとともに， まず歴史的, 社会的見地から関係地域における合意 形成 ${ }^{8)}$ が不可欠であろう.また各自治体においては， 海水淡水化のように安定して確保できる水源を持つ ことは, 渴水時の緊急的な対応が必要な場合などに 有効であると思われる。

このような方策を実現するためには，各自治体に おける利水安全度を定量的に把握し評価できる体制 を確立する必要がある．現実に，自治体や水道事業 者を対象とした渴水に関するアンケート 渴水被害の軽滅を目的とした対策を検討する場合に， 予測や判断のための被害指標や評価基準など, 効果 が数量化されることの必要性が挙げられている，そ こで本研究では, 想定される渴水レベルに応じた水 資源の軍用計画や開発計画について，各自治体にお ける利水安全度の応答のシミュレーションを目的に リスク解析 ${ }^{(0)}$ 導入する.リスク解析は, 渴水時にお いて対象となる水供給システムを, 信頼度, 回復度, 深刻度と，これらの総合的な指標であるDRI (Drought Risk Index)によって評価する手法である. これまでに筆者らは，リスク解析が自治体における 水源の特性や施設の能力および自己水源の開発可能 量などを評価する際の有効な手法のひとつであるこ とを示している ${ }^{10,11)}$.

\section{II. 本研究の韭景と目的}

A 都市圈では，都市圈の流域に一級河川を持たず， 地理的な制約などによって水資源の賦存量が少ない ことから，流域外の一級河川である E川からの導水 を受けている(图一 1 参照). A 都市圈における E川运 水への依存度は, 中心都市のA市で日配水量の約 $30 \%$ ，周辺自治体で日配水量の $20 \sim 50 \%$ と高い. $\mathrm{A}$ 市は自己水源の充実にも力を入れているが，周辺自 治体ては地理的・経斉的制約から，充分に自己水源 が確保されているとは言い難い状況も見られる。こ のため, E川の流況が悪化し導水の制限が行われた
場合に，A市と比較して周辺自治体の影響は大きい と考えられる.

このような状況の中, 近年 $\mathrm{A}$ 都市圏では平成 4 年 度と平成 6 年度に渴水が発生した。A市における年 間降雨量について105年間の非超過確率を図ー 2 に

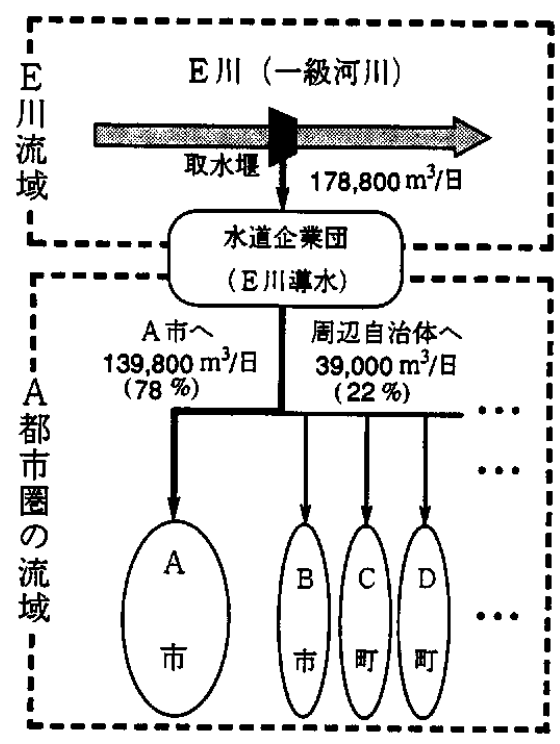

图一1 A 都市圆における流域外からの荅水

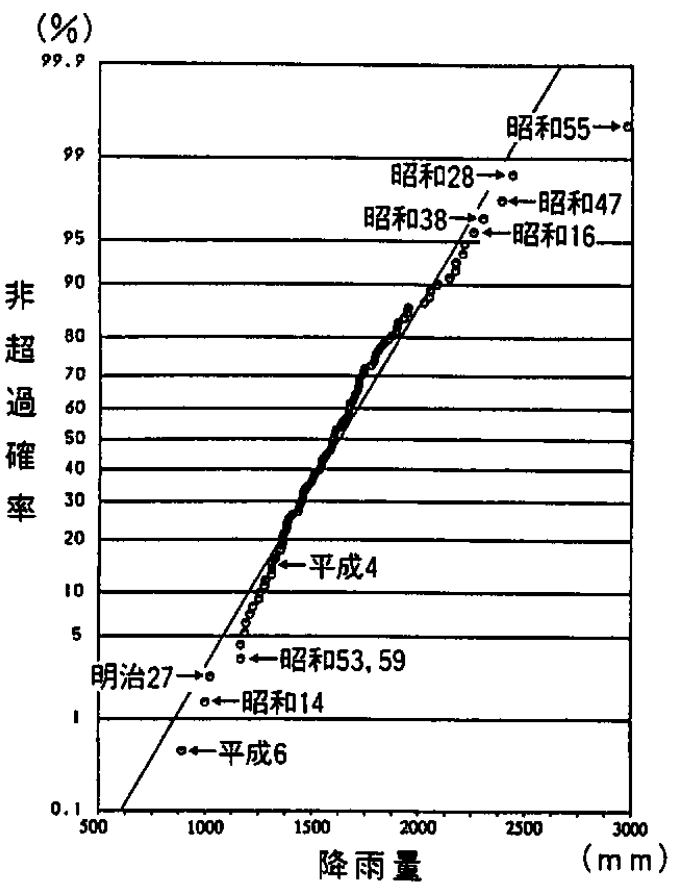

図ー2 A市管区気象台における降雨量の非超過確率 
示す. 図中の直線は正規分布に対応する.これより, 平成 4 年は約 $1 / 6$, 平成 6 年は観測史上最大の約 $1 / 167$ 程度の渴水であったことがわかる.平成 4 年度 の渴水は, A都市圈では非超過確率で $1 / 6$ 程度の降雨 があったが，E川流域では $1 / 25$ 程度と降雨が少なく 流況が悪化し，E川導水量が制限されたことが主な 原因である、A市は比較的余裕があった自己水源で 対応し影響は少なかったが, 周辺自治体では $\mathrm{E} 川$ 導 水の依存度が高いことから被害を受け，同じ都市圈 の中でも被害の程度に相違が生じた. 平成 6 年度の 渴水は, A市で105年間の観測史上第 1 位の少雨を記 録するなど，A都市圈を含む周辺地域全体の高温・ 少雨が原因である.この大規模渴水は, 安定的な新 規水資源を確保することの必要性を提示した。これ らの渴水を受けて, 都市圏全体の水資源を広域的に 利用することや, 海水淡水化のような安定した新規 水資源の確保など, 行政 ${ }^{13)}$ や市民 ${ }^{14)}$ も認識を等しく している. 現在は今後の具体的な施策に期待されて いる状況である。

本報では，A都市圏の中心都市である $\mathrm{A}$ 市につい て, 想定する渴水レベルの事例として平成 4 年度と 平成 6 年度の渴水を対象に, リスク解析を用いたシ ミュレーションを実施し, 求められるリスク指標に より, 渴水対策として水資源の広域利用と安定水源 の確保が利水安全度に及ほす影響を検討する。すな わち, 平成 4 年度の渴水のような比較的小規模な渴 水の場合に，A市の水資源の一部を自己水源の状況 が悪化していた周辺自治体に融通することで, A 都 市圏全体の利水安全度が向上すると考える。このシ ナリオに基づいたシミュレーションによって, 水資 源の広域利用を実施した場合の, A市の利水安全度 に及涩寸影響と広域利水の可能性をリスク指標によ

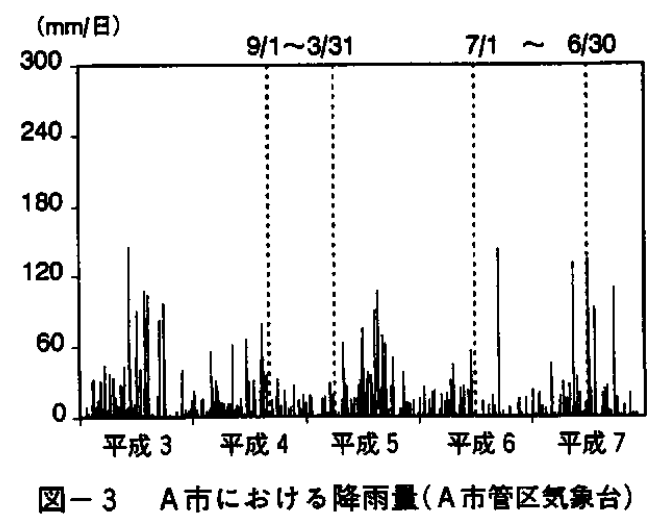

り検討する. また，平成 6 年度のように大規模な渴 水では, $\mathrm{A}$ 市の水資源の一部を融通することは難し いと思われる. そこでA市に, 海水淡水化のように 安定して確保できる新規水源の導入を考える。この シナリオに基づいたシミュレーションによって, 安 定した水源の確保が，A市の利水安全度の向上に与 える効果をリスク指標により検討する。

\section{A 都市图における水資源の概要}

事例解析の対象とするA都市圏における水資源の 概要を述べる. 近年, A市とそのベットタウンとし ての周辺自治体は, 地方における文化・経済の一極 集中により人口が増加し, 水需要量の増加が続いて いる。また, A都市圏には一級河川がなく, 後背地 が浅いことからダムの建設適地にそしいなどの地理 的制約がある.A市を含む流域における平均降雨量 は $1,845 \mathrm{~mm} /$ 年, 人口一人当たりでは $1,902 \mathrm{~m}^{3} /$ 年であ り, 全国の平均降雨量の $1,749 \mathrm{~mm} /$ 年と比較すると概 ね同量であるが，人口一人当たりでは全国平均

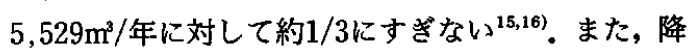
雨量の半分以上は 6 月の梅雨期から 9 月の台風期に 集中してょり，この時期に充分な降雨がなければ水 資源の運用に大きな影響を与える. 平成 $3 \sim 7$ 年の $\mathrm{A}$ 市管区気象台の降雨量を图一 3 に, E川上流域に おける降雨量を图一 4 に示す。特に平成 6 年度は, いずれの流域においても降雨量が少ないことがわか る.これにより，A市が水利権を持つ貯水池の有効 貯水量も激減した (図一 5 参照)。また，図一6に示す ようにE川の流況の悪化によって された. 図一 7 に平成 $3 \sim 7$ 年のA市の実績配水量 を示す.ところで, 平常時 (渴水でない場合)の害際の 水運用では, 需要量の予測を行いそれを満足させる

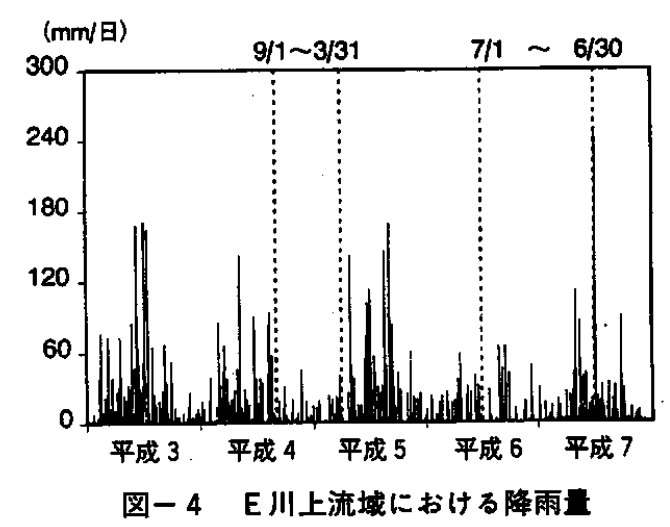



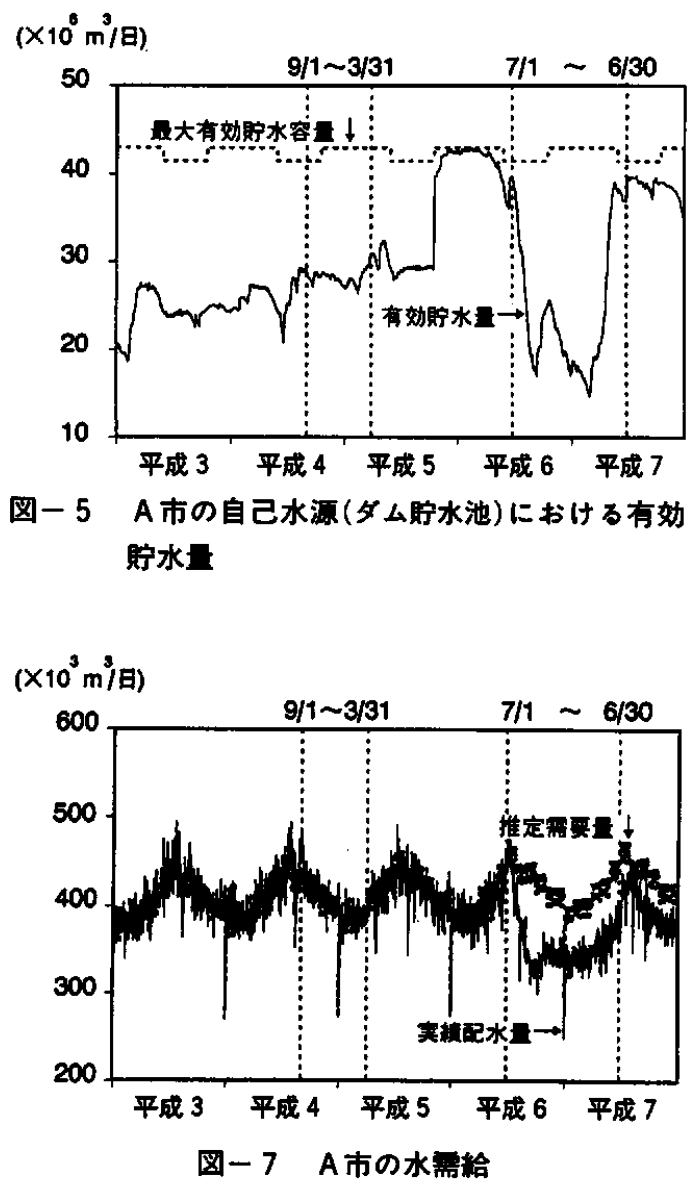

ように供給を行うため, 需要量と供給量は一致して いる. ところが, 渴水時には水源の状況か悪化して いるため, 予測された需要量に応じた水量が確保て きず，供給量は減少する，このように，渇水時の需 給を検討する場合には需要量の推定が必要である。 本報では，式(1)に示す推定モデルにより求められた 推定需要量をV.のシミュレーションに用いている.

$$
\begin{aligned}
Q(t)= & 14.91 t+403,392 \times \text { (月係数 }) \\
& \times \text { (曜日係数または特殊日係数 })
\end{aligned}
$$

これは, トレンド, 月, 曜日, 特殊日による変動 を考虑した日供給量推定式 ${ }^{17)} に よ り$ 求めたもので, トレンド成分を除いた值に各月の係数を乗じ,さら に特殊日においては特殊日係数を，それ以外の日に は曜日係数を乗し，最後にトレンド成分を加えるこ とを意味する. トレンドの算定には平成 $3 \sim 5$ 年の

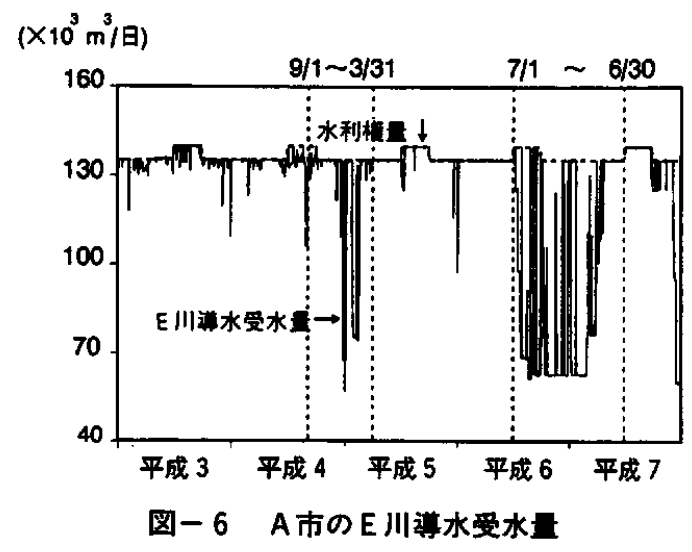

3 年間のデー夕を用いており,この推定式の実績配 水量に対する平均誤差率は $3.56 \%$ ある。 このよう にして求めた平成 $6 \sim 7$ 年の推定需要量を图一 7 中 に示している，なお図ー3〜 7中には，本報で対象 とした平成 4 年度および平成 6 年度渴水の事例解析 のシミュレーション期間を破線で示している。

\section{IV.リスク解析の学入と指柴の定義}

利水安全度は水資源の利用に関する安定性を表す 概念であり，不足\%・日や不足\% ${ }^{2}$ ・日など代表的な 指標のほかに, 渴水の「長さ」,「大きさ」,「䈆し さ」,「経済的被害」など, 渴水発生後の渴水被害を 表現するいくつかの指標が用いられている4,18). 本研 究では, リスクを表す,「信頼度」,「回復度」,「深刻 度」の 3 つの指標 ${ }^{10)}$ と, 新たにDRI (Drought Risk In$d e x)$ を導入する.これらの指標の定義を以下に簡単 に述べる.

(1) 信頼度 (Reliability)

水供給システムが, 必要な水量の基準を満たす 確率であり, 次式によって求められる.

信頼度 $=($ 供給量 $\geqq$ 需要量)を満たす日数

$$
\text { /対象期間日数 }
$$

(2) 回復度 (Resiliency)

渴水の継続性や立ち直りの早さを表し, 次式に よって求められる.

$$
\text { 回復度 }=\text { 渴水の発生回数/渴水日数 }
$$

回復度の逆数は一度渴水に陥った時の平均継続 期間を意味する。

(3) 深刻度 (Vulnerability)

渴水の深刻さの度合を示す指標であり, 次式に よって求められる。

深刻度 $=$ 渴水期間中の総不足量 
／渴水期間中の総需要量

深刻度は渴水期間中の平均不足率を意味する。

(4) DRI (Drought Risk Index)

現実の施策上では，さまざまな渴水の状況を同 時に把握して評価を行う場合も多いと思われる。 このような場合に，渴水のどのような状況を重視 するか，重み付けを含めた評価を行うことが可能 な指標が必要となる，そこで，(1)（3)の 3 つの指 標の重み付き線形和をDRI として新たに定義し 総合的なリスクの指標とする.すなわち,

$$
\begin{aligned}
D R I= & w_{1} \cdot(1-\text { 信頼度 })+w_{2} \cdot(1-\text { 回復度 }) \\
& +w_{3} \cdot \text { 深刻度 }
\end{aligned}
$$

であり， $w_{1}, w_{2}, w_{3}$ は各指標に対する重み係数で ある。評価の対象としている水供給システムにお いて，いずれの指標を重視するかにより係数を変 化させた評価が可能である. 信頼度, 回復度, 深 刻度のそれぞれの指標が 0 から 1 の間の值である ため, $D R I$ も式(5)の定義から同様の範囲で評価さ れる。

\section{V.A市におけるシミュレーションと結果の 考察}

\section{1. 平成 4 年度渴水( $\mathrm{A}$ 市の水資源を周辺自治体に} 融通する场合)の検討

\section{1）シナリオの設定}

A市の水資源の一部を自己水源の状況が悪化して いた周辺自治体に融通した場合の，A市の利水安全 度に与える影響を検討する。すなわち，A都市圏へ のE川導水において，A市の受水量の一部を周辺自 治体に振り当てる方策を考える，ここでは，E川導 水の水量が制限された平成 4 年 9 月 1 日から平成 5 年 3 月31日までの 7 ヶ月間を渴水期間とみなして, シミュレーションの対象期間とする。 また，以下に 示すシミュレーションのシナリオを設定する.

ケース(1)：自己水源のダム流入量と河川取水量の 実績值を用い, E川導水の受水量を変化させた場合. これは，A市では水文状況として平成 4 年度の実績 值を用いるが, E川導水からの受水量が制約される ケースを想定している.

ケース(2)：自己水源のダム流入量を平成 4 年度の 実績に対して減少させるとともに，ダ貯水を温存 するためにダム取水量を制約させるが，河川取水量 は実續値を用い，E川導水の受水量を変化させた場 合.これはA市の運用として, ダム貯水の温存およ び河川取水優先という方針に対応している.
ケース(3)：自己水源のダム流入量と河川取水量の 両者を減少させ, $\mathrm{E} 川$ 埒水の受水量を変化させた場 合.これは，A市において降雨量が少なく自己水源 のダム取水量が減少し, 流況の悪化により河川取水 量も減少したケースを想定している.

なお，A市のE川導水の受水量は, 水利権量を受 水率100\%とする. また, ケース(2), (3)の, 自己水源 のダム流入量および河川取水量の減少は, 降雨量の 隇少が反映されるとして, 対象期間における降雨量 の非超過確率 $1 / 10,1 / 20,1 / 30$ の渴水年降雨量を求 め, 実績降雨量との比で自己水源のダム流入量およ び河川取水量の実績值から減少させた(表一1参照). 本来ならば，降雨量に基づいた流入量予測を行うべ きであるが，ここでは利水安全度の検討を主な目的 としているため,このように簡便な手法をとってい る.また，E川導水の受水量が制約された場合，需 要量を満たすために不足量は自己水源のダムから取 水すると仮定する。

\section{2）結果と考察}

上述したシナリオに基づくシミュレーションの結 果について，ケース毎に考察する.

\section{表一 1 平成 4 年度渭水における降雨量の実維值と

\begin{tabular}{|c|c|c|}
\hline \multicolumn{3}{|c|}{$\begin{array}{c}\text { 平成4年度渴水のシシュレージン期间の降雨量 } \\
\text { (平成4年9月1日一平成5年3月31日) }\end{array}$} \\
\hline 確率渴水年 & 渴水年降雨竟 & 実維降雨量との此 \\
\hline $1 / 10$ 晹水年 & 496 & 0.944 \\
\hline $1 / 20$ 㴓水年 & 452 & 0.861 \\
\hline $1 / 30$ 晹水年 & 429 & 0.817 \\
\hline
\end{tabular} 理論值の比}

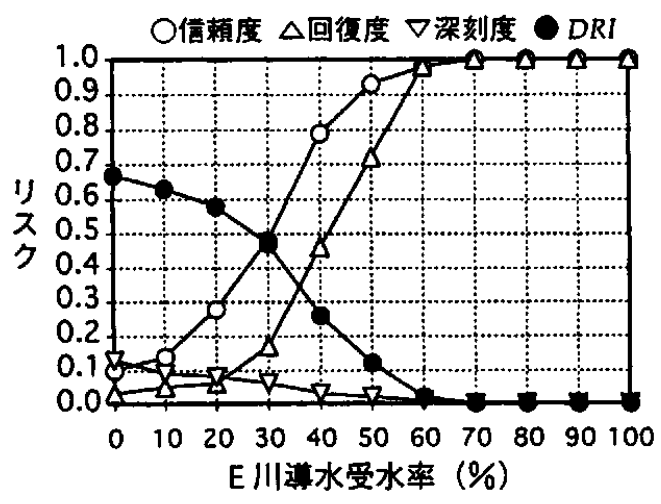

図ー8 ケース(1)：实繶運用によるリスク指梅 
ケース(1)：対象期間中の実績配水量と推定需要量 を用いて，E川導水の受水率を変化させたシミュ レーションで求められたリスク指標を図ー8に示す.

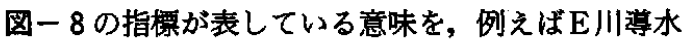
の受水率が $30 \%$ の場合に着目して述べる. 受水率が $30 \%$ のをき, 信頼度は 0.48 , 回復度は 0.18 , 深刻度 は0.05，DRIは0.45である。これは，対象期間中の $\mathrm{E} 川$ 受水率が $30 \%$ に制約されると，信頼度は 0.48 , つまり対象期間中の $48 \%$ 期間のみて配水量が需要 量を満足し，残りの $52 \%$ 期間が渴水状態であるこ とを表している．回復度は0.18となっており，この 逆数が約5.6であることから,一度渴水状態に陷った 場合の平均継続期間が約 6 日間であることを表して

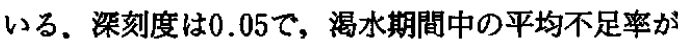
$5 \%$ \%ることを表している.ささらに，信頼度，回 復度, 深刻度を同じ重みで評価した場合, すなわち 式(5)の各指標に対する重み係数 $w_{1}, w_{2}, w_{3}$ を $1 / 3$ と したDRIは0.45となっている。

次に，図一 8 から，E川導水の受水率が70\%に制 約されても, 信頼度, 回復度, 深刻度およびDRI は 生じないことがわかる。このことから平成 4 年度の 渴水レベルでは，A市におけるE川導水量の $30 \%$ (約 $42,000 \mathrm{~m}^{2} /$ 日)を周辺自治体に融通することが可能て あると考えられる。この約 $42,000 \mathrm{~m}^{3} /$ 日は, A市の周 辺自治体における 1 人 1 日平均給水量が約 370 リッ トル/日/人沾,16) とすると, 約 113,500 人/日の給水量 に相当する.

ところで, 渴水期間は可能な限り短い方が望まし い. しかしながら一般的な取水運用, 特に渴水時に おいては，貯水池の水を温存する方針に基づく場合 が多いと考えられる。すなわち，渴水期間は短いが 一日当たりの不足率が非常に大きい渴水よりも, 渴 水期間が多少長くても生活に支障をきたさない程度 の一日当たりの不足率を目指した運用である。これ は, リスク指標の回復度や深刻度を重視して検討す ることに相当する。 そこで, 信頼度, 回復度, 樑刻 度のいずれかの指標を，残りの指標の 2 倍に重視し た場合，つまり，式(5)の重視したい指標の重み係数 を $1 / 2$, 残りの指標の係数を $1 / 4$ に考えた場合の $D R I$ を図ー9に示す，图一 9 において，例えばDRIが 0.2 場合に着目すると, 回復度を重視した $D R I\left(w_{1}\right.$ $\left.=1 / 4, w_{2}=1 / 2, w_{3}=1 / 4\right)$ の受水率は $48 \%$, 深刻度を 重視したDRI $\left(w_{1}=1 / 4, w_{2}=1 / 4, w_{3}=1 / 2\right)$ の受水率 は $40 \%$ ある.これは, 期間中の平均不足率が多少 大きくなっても，渴水の平均継続期間を短くしたい
場合には48\%の受水率が必要であることを示してい る.一方, 渴水の平均継続期間が長くなっても, 期 間中の平均不足率を小さくしたい場合は，40\%の受 水率が必要であることを示している．また，前者と 比較して後者は, E川導水の受水率て $8 \%$ の多くの 水量を周辺自治体に融通できる可能性を示している が, この水量をA市は自己水源から取水して補う必 要がある.このように, DRIが等しい状況でも，い ずれの指標を重視するかにより，運用方策の目的に 応じて必要な水量を検討することが可能である.

以上のような渴水りスクの検討を行う場合に，図 ー10のように評価ダイアグラムとして視覚化すれば, $D R I$ をばめとするそれぞれの指標の大きさやバ ランスが把挃しやすいと考えられる。これは, 信頼 度リスク : $\mathrm{R}_{1}=w_{1} \cdot(1$ - 信頼度), 回復度リスク: $\mathrm{R}_{2}=w_{2} \cdot\left(1\right.$ - 回復度), 樑刻度リスク : $\mathrm{R}_{3}=w_{3}$ ・ 深刻度と定義した, $R_{1}, R_{2}, R_{3}$ を軸として, 三角形 の面積が大きいほどリスクが大きいことを表す．四 -10は例として，図ー8に示すケースで受水率が $30 \%$ の場合の渴水リスクを評価ダイアグラムで示し ている。

ケース(2)：A市の降雨量が非超過確率で $1 / 10$, $1 / 20,1 / 30$ になり，この影㮫で自己水源のダム貯水 池への流入量が減少し，ダム貯水の温存のため取水 量を制約するが，河川水源地からの取水は実綪通り に行われた場合の配水量と, 推定需要量の関係から 求められたリスクを图ー11〜13に示す.

降雨量が非超過確率で $1 / 10$ (図-11) と $1 / 20$ (图一 12)の場合，E川導水の受水率が70\%に制約されても， いずれの指標からもリスクは生じないことがわかる. 降雨量が非超過確率で $1 / 30$ (图-13)の場合, 受水率 が $80 \%$ に制約されるとリスクが生じることがわかる. このことから降雨量の非超過確率が1/10１/20では， A市におけるE川導水量の $30 \%$ (約 $42,000 \mathrm{~m} /$ 日)を, $1 / 30$ では $20 \%$ (約 $28,000 \mathrm{~m}^{3} /$ 日) を周辺自治体に融通す ることが可能であると考えられる. 图一13に示して いるように，A市の流域で降雨量の非超過確率が $1 / 30$ の場合でも, 受水率が60\%であれば, 信頼度は 0.96 (対象期間の $4 \%$ が渴水), 回復度は 0.85 (平均継続 期間が1.2日), 深刻度は0.02(期間中の不足率が $2 \%$ ), $D R I$ は 0.06 となり, 渴水被害としての影響は比較的 小さい.

また，図ー14は例として，図ー13に示すケースで 受水率が $30 \%$ の場合の渴水リスクを評価ダイアグラ ムで示している。 


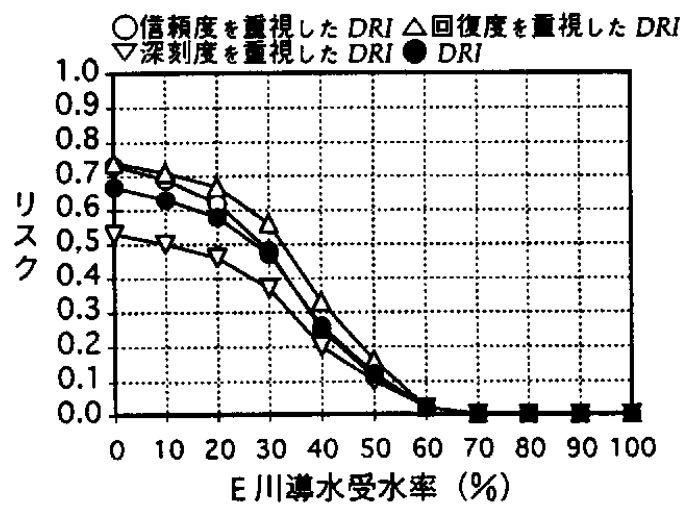

図ー9 ケース(1)：各指標を更視したDRI

信頼度りスク:R

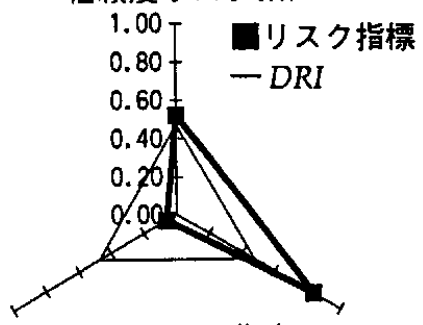

深刻度リスク: $\mathrm{R}_{3}$ 回復度リスク: $\mathrm{R}_{2}$

图一10 渴水リスクの評価ダイアクララム （実績運用，受水率 $30 \%$ )

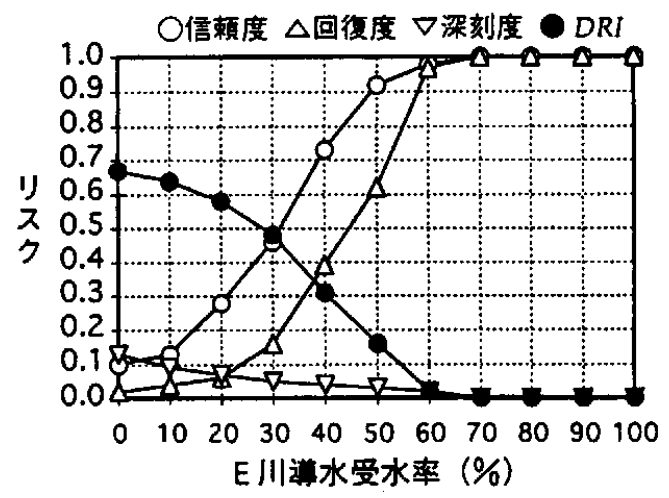

図一11 ケース(2):1/10渴水年のリスク指標

次に, 降雨量の非超過確率が1/10の場合について, ケース(1)と同様に各指標に重み付けをした $D R I を$ 图ー15に示す.ケース(1)の検討と同じように，例え ばDRIが0.2の場合に着目すると，回復度を重視し たDRIによる受水率は $51 \%$ であるが, 深刻度を重視 したDRIによる受水率は $46 \%$ であ. 渴水の平均継 続期間の短縮を目的にする場合と, 期間中の平均不

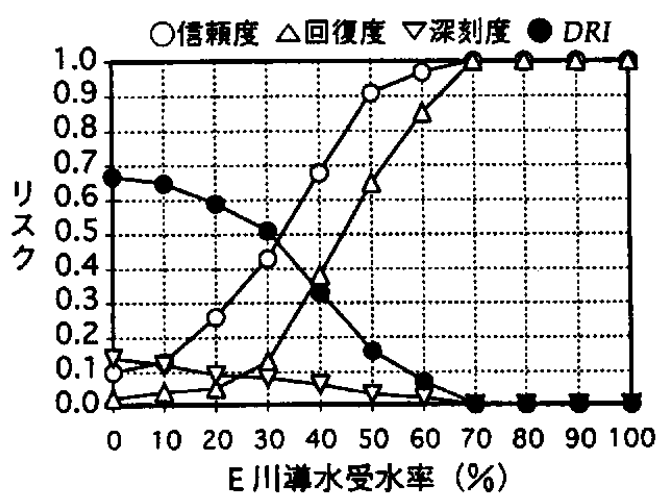

图-12 ケース(2): 1/20湿水年のリスク指栖

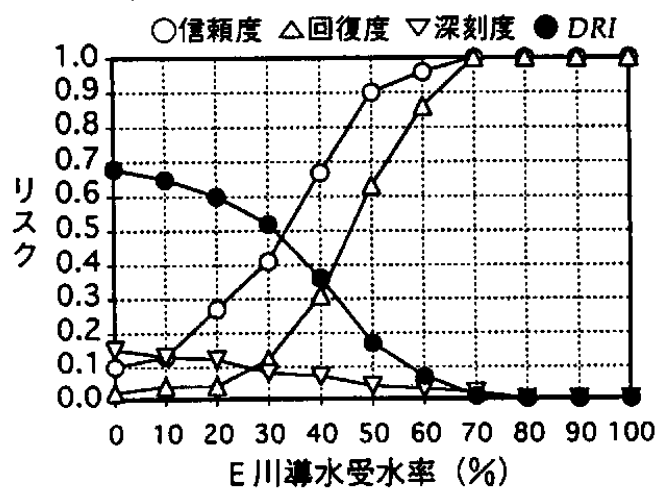

图ー13 ケース(2)：1/30渴水年のリスク指柾

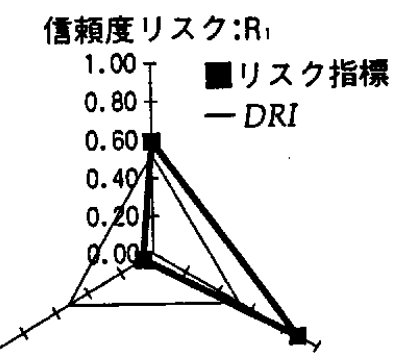

深刻度リスク: $\mathrm{R}_{3}$ 回復度リスク: $\mathrm{R}_{2}$

图-14 渴水リスクの評価ダイアクラム $(1 / 30$ 渴水年, 受水率 $30 \%)$

足率の隇少を目的にする場合では受水率に約 $5 \%$ の 差が生じる.これは，深刻度を重視したDRIでは, 回復度を重視した $D R I$ と比較して，E川導水の受水 率で $5 \%$ 多くの水量を周辺自治体に掘通できる可能 性を示しているが，一方でこの水量を A市は自己水 源から取水して補う必要がある。

ケース(3)：A市の降雨量が非超過確率で1/10, 


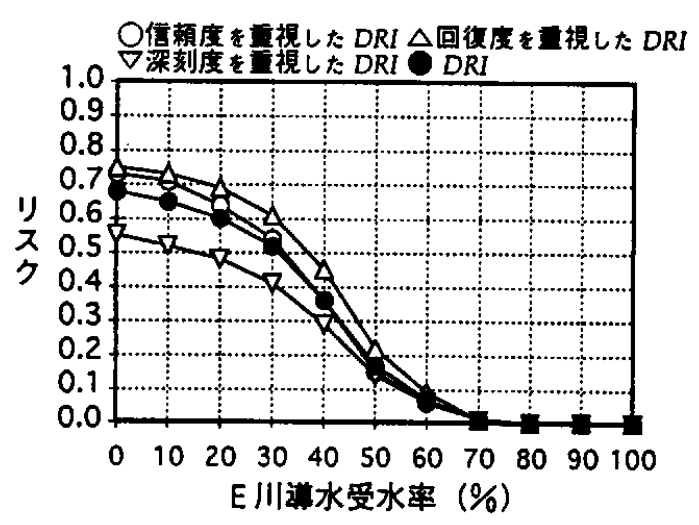

图一15 ケース(2)：各指標を重視したDRI

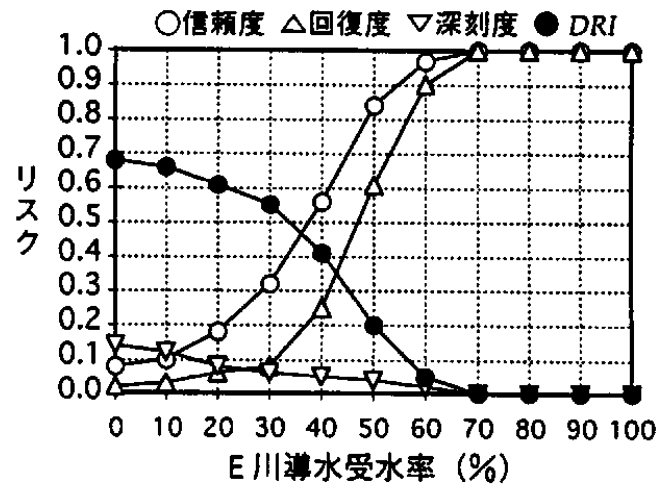

図-16 ケース(3):1/10渴水年のリスク指梅

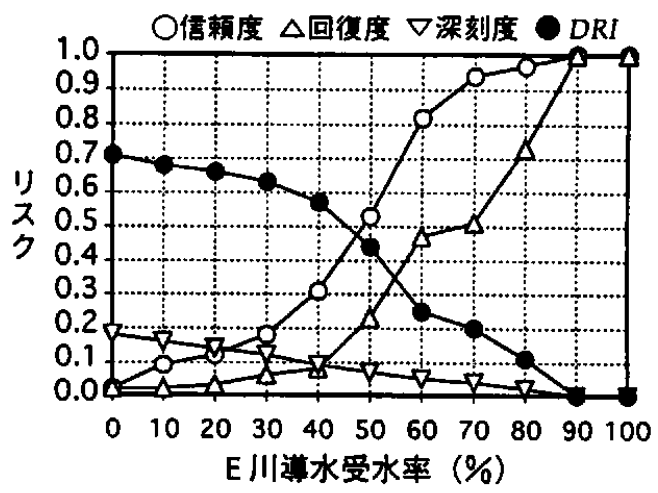

図-17 ケース(3):1/20渴水年のリスク指樦

$1 / 20,1 / 30$ になり，この影響で自己水源のダム貯水 池への流入量が減少し，河川の流況も悪化したこと によって，両者の取水が制限された場合の配水量と， 推定需要量の関係から求められたりスクを图一16〜 18に示す.

降雨量が非超過確率で1/10(図-16)の場合, ケー

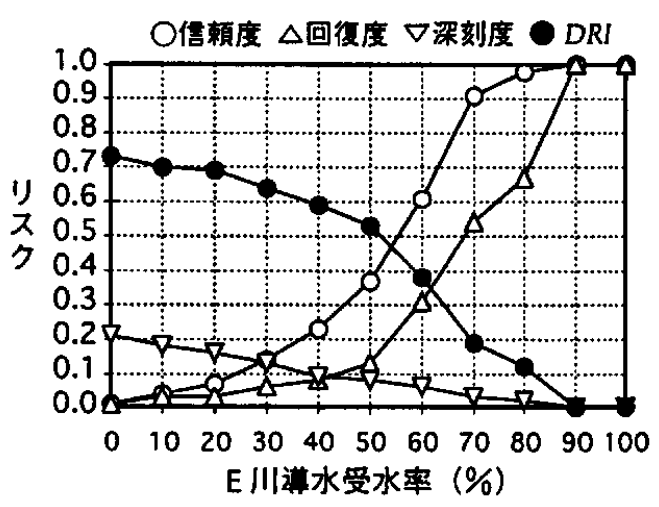

図-18 ケース(3):1/30渴水年のリスク指梅

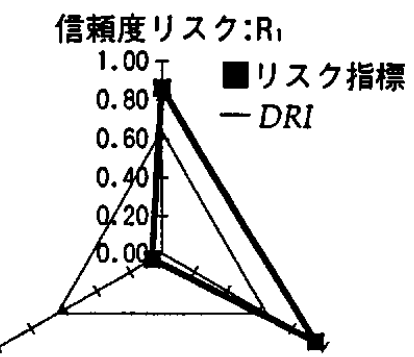

深刻度リスク: $\mathrm{R}_{3}$ 回復度リスク: $\mathrm{R}_{2}$

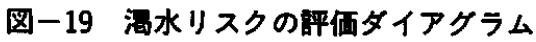
$(1 / 30$ 渴水年, 受水率 $30 \%)$

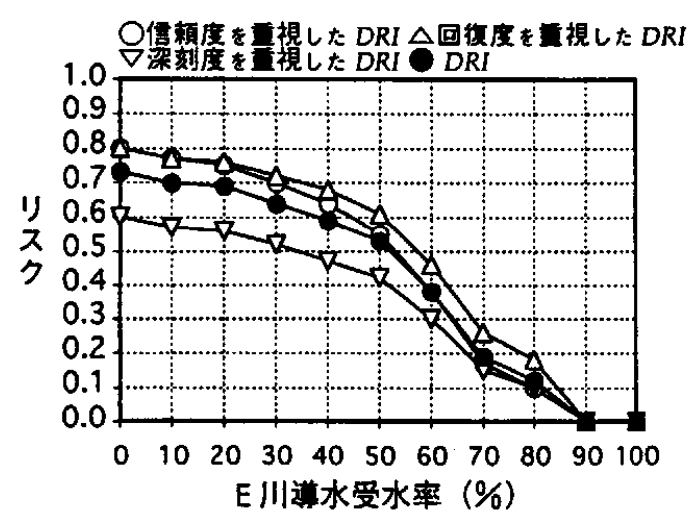

图ー20 ケース(3)：各指標を臬視したDRI

ス(1)の場合と同様に，E川導水の受水率が70\%に制 約されても，いずれの指標からもリスクは生じない ことがわかる。降雨量が非超過確率て $1 / 20$ (图-17) および $1 / 30$ (図-18)の場合，受水率が $90 \%$ に制約さ れるとリスクが生じることがわかる。このことから 降雨量の非超過確率が1/10では，A市における E川 


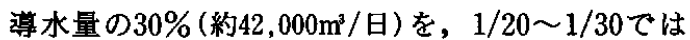
$10 \%\left(\right.$ 約 $14,000 \mathrm{~m}^{3} /$ 日) を周辺自治体に融通することが 可能と考えられる.

また，図一19は例として，図ー18に示すケースで 受水率が $30 \%$ の場合の渴水リスクを評価ダイアグラ ムで示している.

次に, 降雨量の非超過確率が1/10の場合について, ケース(1)と同様に各指標に重み付けをしたDRIを 図ー20に示す.ケース(1)および(2)の場合と比較して， いずれの指標を重視したDRIも, 受水率が $90 \%$ 以下 になるとリスクが生じることがわかる.

以上のヶース(1)〜3)の考察を通じて, 平成 4 年度 の渴水レベルにおいては，A市の水資源の一部を周 辺自治体に融通することは可能であることがわかる. 最も条件の戦しいシナリオであるケース(3)の市の 降雨量を非超過確率で $1 / 30$ と想定した場合で，A市 のE川導水量の $10 \%$ (約 $14,000 \mathrm{~m}^{3} /$ 日)を周辺自治体に 融通することが可能であることがわかった，約 $14,000 \mathrm{~m}^{3} /$ 日の水量は, A市の周辺自治体における約 37,800 人/日の給水量に相当し,これを渴水の程度に 応じて周辺自治体に融通できれば, 利水安全度が改 善されると考えられる。

\section{2. 平成 6 年度渴水 (A 市に安定水源を確保した場} 合)の検討

\section{1）シナリオの設定}

平成 6 年度のような大規模渴水の場合, $A$ 都市圈 においては，水資源の広域利用による利水安全度の 向上は困難であったと思われる，そこで，A市に海 水淡水化のような安定した新規水資源を確保した場 合の, 利水安全度に与える効果を検討する.

$\mathrm{A}$ 市の自己水源のダム貯水量が急激に減少を始め た平成 6 年 7 月 1 日から, 給水制限が解除された平 成 7 年 6 月 30 日までの 12 月間を渴水期間とみなし て, シミュレーションの対象期間とする。この期間 に安定確保量を導入した場合の配水量と, 推定需要 量の関係から求められたリスクを図一21に示す。な お, 導入する安定確保量は, 実績配水量に安定確保 量を加えた場合, 推定需要量を超えない範囲とした.

\section{2）結果と考寒}

图一21の回復度と $D R I$ に着目すると, $90,000 \mathrm{~m}^{3} /$ 日の確保量を導入すれば，リスクは生じないことが わかる。また，例えば $70,000 \mathrm{~m}^{3} /$ 日の確保量を導入し た場合の回復度に着目すると, 安定確保量を導入し ない場合 (回復度は 0 で期間中の全てで渴水状態) と比
較して, 回復度は0.25(渴水の平均継続期間は 4 日)ま で向上する.一方DRIに着目すると, 約 $61,000 \mathrm{~m}^{2} /$ 日 の安定確保量を導入すれば，導入しない場合と比較 してリスクは約 $50 \%$ に軽滅されることがわかる。図 -22は例として,図一21に示すケースで $60,000 \mathrm{~m}^{3} /$ 日 の安定確保量を導入した場合の渴水リスクを評価ダ イアグラムで示している.

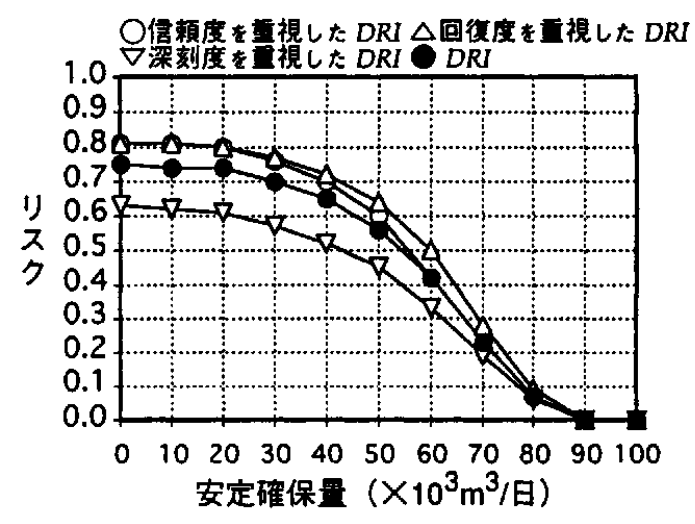

図一21安定水源を確保した场合のリスク指標

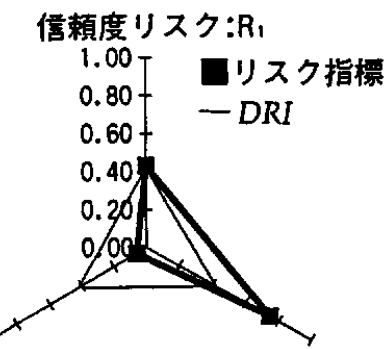

深刻度リスク: $\mathrm{R}_{3}$ 回復度リスク: $\mathrm{R}_{2}$

\section{図ー22 渴水リスクの評価ダイアグラム (安定確保量 $60,000 \mathrm{~m}^{3} /$ 日)}

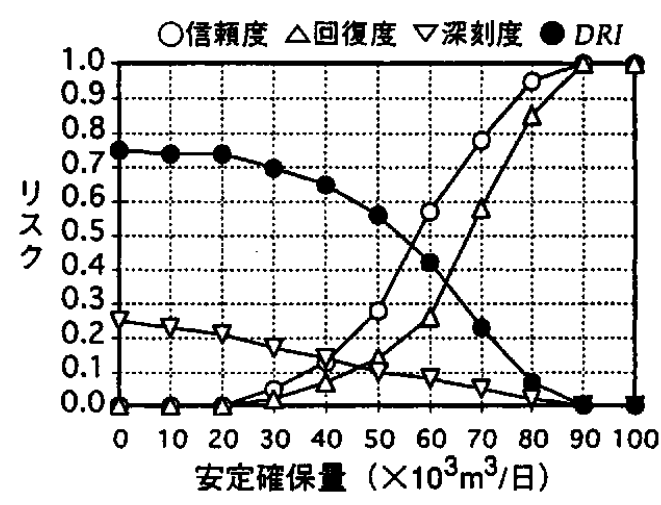

图ー23各指綵を重視したDRI 
V.1.の各ケースと同じように,各指標に重み付け をしたDRIを図ー23に示す。例えば,リスクを 0.4 ま で低下させたい場合, 回復度を重視したDRIでは約 $64,000 \mathrm{~m}^{3} /$ 日, 深刻度を重視したDRIでは約 55,000 m³/日の安定確保量を導入する必要がある.これは, 渴水の平均継続期間の短縮を目指す場合は, 渴水期 間における平均不足率の減少を目指す場合と比較し て, 約 $9,000 \mathrm{~m}^{3} /$ 日のより多くの水量が必要であるこ とを示している．このように，それそれの指標に重 み付けを与えたリスクを検討することは，渴水方策 の決定と安定確保量の算定に有効な手法と考える.

\section{VI. おわりに}

本研究では, 利水安全度の評価にリスク解析を導 入し，信頼度，回復度，深刻度および新たに総合的 な指標としてDRIを定義した.これらの指標を用い た渴水レベルの事例解析として，A市における平成 4 年度および平成 6 年度の渴水を対象に，A市の水 資源を周辺自治体へ融通することおよび安定水源の 確保という対応方策が利水安全度に与える影響や効 果を検討した. 得られた主な結果を以下に示す.

(1) A市で平成 4 年度に発生した渴水レベルの水運 用においては，E川導水の受水率が70\%あれば $\mathrm{A}$ 市のリスクに影響はない,これは, A市の周辺自 治体に約 $42,000 \mathrm{~m}^{3} /$ 日(約 113,500 人/日)の給水量を 融通できる可能性を示している.

(2) $\mathrm{A}$ 市の平成 4 年度の水運用において, 降雨量の非 超過確率によって自己水源のダム貯水池と河川水 源地からの取水量を制限したシミュレーションを 行ったところ, 非超過確率 $1 / 10 て 70 \%, 1 / 20 〜 1 /$ $30 て ゙ 90 \%$ の受水率があれば利水安全度への影響は ない.これは降雨量が非超過確率 $1 / 20 \sim 1 / 30$ の場 合で, A 市の周辺自治体に約 $14,000 \mathrm{~m}^{3} /$ 日 (約 37,800 人/日)の給水量を融通できる可能性を示し ている.

(3) 平成 6 年度に発生した渴水レベルの水運用にお いては, 安定的に $90,000 \mathrm{~m}^{3} /$ 日の水量を確保すれば リスクは生じない.一方, 約 $61,000 \mathrm{~m}^{3} /$ 日の安定確 保量を導入すれば，導入しない場合と比較してり スクは約 $50 \%$ に軽減されることがわかる.

(4)このような考察を通して,リスク解析を用いたシ ミュレーションによって求められるDRIをはじ めとしたリスク指標を検討することは，水道事業 の広域化や水資源計画など, 渴水レベルに応じた 被害の軽減を目的とした施策の検討や効果の予測
を評価する上で有効な手法といえる.

謝辞: 本研究は, 文部省科学研究費補助金(総合研究 (A)「平成 6 年度渴水の気象・水文学的検証と渴水時のリ スクマネジメントに関する研究」研究代表者：池淵周一) の助成を得ました。また，貴重なデータとご意見を いただいた，A市およびA都市圈の水道管理に携 わっておられる職員の方々に深く御礼申し上げます.

\section{参考文䘞}

1) 丹羽 薰 (1991)：地球温暖化と水資源, 用水と 廃水, Vol. 33, No. 1, pp. 35-42.

2) 千賀祐太郎 (1989)：水資源のソフトサイエンス, 鹿島出版会。

3 ）中澤式仁 (1981)：水管理の考え方, 土木学会誌, 1981-5, pp. 9-15.

4) 池淵周一(1988)：水資源システムにおける安全 度概念の定式・定量化と計画論への応用に関す る総合的研究, 昭和 61,62 年度科学研究補助金 研究成果報告鲁.

5) 志村博康 (1995)：渴水に対する 3 つの対応ス テージと将来的課題, 水道協会雑誌, Vol. 64 , No. 7, pp. 77-82.

6 ）浜田康敬 (1995): 渴水と水道, 水道協会雑誌, Vol. 64, No. 7, pp. 73-77.

7 ) 鏑木儀郎 (1995): 平成 6 年渴水と今後の水道整 備, 土木学会誌, Vol. 80, No. 8, pp. 84-86.

8 ）志水茂明(1981)：水資源問題の現場から需給と 開発を語る〜水需給の長期見通し, 土木学会誌, 1981-5, pp. 19-22.

9 ）白水惕・友野勝義 (1995)：水道におけるリスク 管理の現状, 水道協会雑誌, Vol. 64, No. 1, pp. 32-41.

10) Tsuyoshi HASHIMOTO, Jery R. Stedinger, Daniel P. Loucks (1982): Reliability, Resiliency, and Vulnerability Criteria For Water Resource System Performance Evaluetion, Water Resources Research, Vol. 18, No. 1, pp. 14-20.

11) Kenji JINNO, $\mathrm{Xu}$ ZONGXUE, Akira KAWAMURA, Kaname TAJIRI (1995): Risk Assessment of a Water Supply System during Drought, Water Resources Development, Vol. 11, No. 2, pp. 185-204.

12) 田尻 要・神野健二・河村 明(1996)：リスク 
解析を用いたA都市圈の自治体における利水安 全度の検討, 水文・水資源学会誌, Vol. 9, No. 5, pp. 404-413.

13） $\mathrm{A}$ 県 (1996)：A 県水資源総合利用計画(第 4 次).

14）九州大学出版会(1996)：A市で学びA市で考え る環境問題, pp. 63-67.

15）A 県水資源対策局 (1994）：A県における水事情 (水資源の現況と今後の主要な課題).
16）社団法人日本水道協会（1993）：水道統計一施 設・業務編一。

17）末吉信一郎・河村 明・神野健二 - 田尻 要 （1993）：A市における日配水量の統計的特性に ついて, 土木学会西部支部1992年度研究発表会 概要集, pp. 123-124.

18）国土庁長官官房水資源部（1994）：日本の水资源 一健全な水循環をめざして一。

(1996年10月 4 日受付, 1997年 2 月27日受理) 